\title{
1007 微視的引張破壊と微視的せん断破壊のモデル化による コンクリートの圧縮破壊シミュレーションに関する研究 Simulation of Compressive Fracture in Concrete by Modeling Microscopic Tensile and Shear Cracks
}

\author{
$\bigcirc$ 神野 真弥(茨城大)＼cjkstart車谷 麻緒(茨城大) \\ Shinya KAMINO, Graduate School of Science and Engineering, Ibaraki University \\ Mao KURUMATANI, Ibaraki University
}

\begin{abstract}
It is well known that cement-based materials form the fracture process zone near crack tip due to material inhomogeneity. It is important that we consider the fracture behavior in fracture process zone because it affects the strength and toughness of materials. In this study, we simulate the compressive fracture behavior in cement-based materials by taking into account the microscopic tensile and shear fracture in fracture process zone. We first explain the formation of microscopic tensile and shear cracks for quasi-brittle materials. Then we compare the simulation result with the experimental result to examine the validity of our numerical model.
\end{abstract}

Key words : Modeling of compressive failure, Microscopic tensile and shear fracture, Fracture process zone, Cohesive crack model, Voronoi diagram

\section{1. はじめに}

コンクリートのようなセメント系材料はその非均質性に 起因し，巨視的なひび割れの先端部分に破壊進行領域と呼ば れる微細なひび割れが累積する領域を形成する. 破壊進行領 域内では微細なひび割れの形成・閉口・連結や骨材の剥離, インターロッキングといった挙動が起こると考えられてい る.こうした破壊進行領域内での破壊挙動は巨視的な強度・ 勒性に影響を与えると言われており，セメント系材料の破壊 挙動を扱う際には, この領域内の挙動を適切に考慮する必要 がある。

セメント系材料の破壊挙動に関する研究に関して，近年， 数值シミュレーションによりその破壊進行挙動を再現しよ うと様々な試みがなされている．例えば，剛体-バネモデル (RBSM） 1) やボクセル有限要素法2) といった手法を使用し セメント系材料の破壊進行挙動を再現しようといった研究 が行われている. しかし, 現在のコンクリートの破壞進行シ ミュレーション手法の多くは近似の多いものがほとんどで ある. そこで, 本研究では無用な近似を極力なくした破壊挙 動のモデル化により, コンクリートの圧縮破壊を再現可能な シミュレーション手法を開発することを目的としている。

\section{2. モデル化と解析手法}

\section{1 破壊のモデル化 ${ }^{3)}$}

例えば, 細骨材とセメントペーストからなるモルタル中に は破壊の発生源となる微小な空隙や遷移帯といった弱い部 分 (弱層) が不均一に存在する. そこで, Fig.1(a)のように幾 何学的な不均一性に優れるボロノイ分割を利用して破壊の 発生源をモデル化し準脆性破壊を表現する.この方法により， 微細なひび割れの発生は Fig.1(b)のように表され, 微細なひ び割れの成長による巨視的なひび割れは Fig.1(c)のように表 される.ここで, 通常の有限要素法を適用できるようにする ため, ボロノイ要素は三角形要素で構成し, 破壊の発生源を 表現するボロノイ要素の境界は 2 重節点としている.また, 本研究において, 破壊進行領域は弾性変形, 引張破壊, せん 断破壊の 3 つの組み合わせで形成されると仮定する.

\section{2 解析手法}

\section{(1) 微細ひび割れの開閉を考慮した弱形式}

本研究では, 破壊面を表すボロノイ要素境界において, 法 線方向・接線方向にバネ (ペナルティ法) を配置することに よって, 引張破壊・せん断破壊による微細ひび割れの形成を 表現する.ここで, 破壊挙動の構成則として, 破壊進行領域

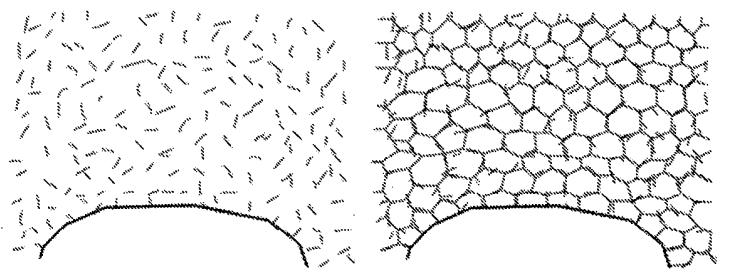

(a) Microscopic structure of heterogeneous material

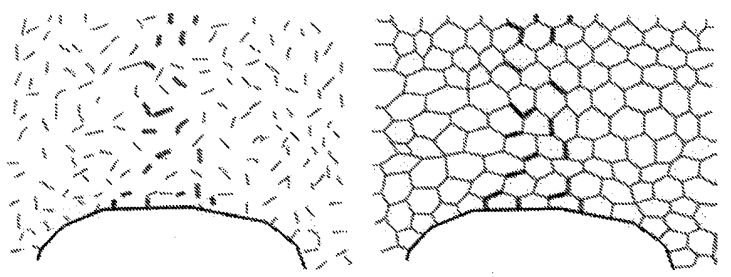

(b) Micro-cracks

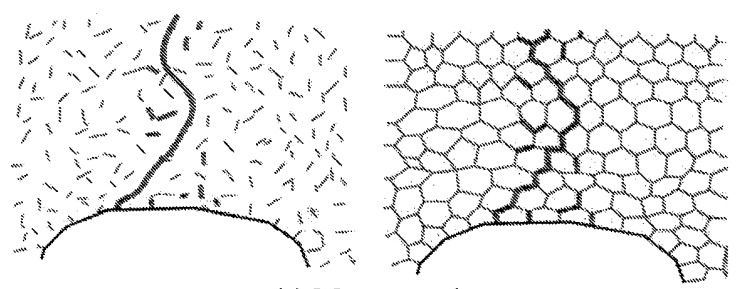

(c) Macro-cracks

Fig.1 Modeling of quasi-brittle fracture

全体を1本のクラックで置き換えたモデルであるCohesive crack model（結合カクラックモデル）を法線・接線方向バネ それぞれに適用し，軟化則として次式を与える.

$$
\left\|t^{\mathrm{coh}}\right\|=f \exp \left(-\frac{f}{G_{\mathrm{f}}} \kappa\right)
$$

ここで, 法線方向バネの場合には $\left\|\boldsymbol{t}^{\mathrm{coh}}\right\|$ は法線方向結合力心゙ クトルの大きさ, $f$ は微視的な引張強度, $G_{\mathrm{f}}$ は微視的な引張 破壊エネルギー, $\kappa$ は載荷履歴における微細ひび割れの最大 開口変位となる. 接線方向バネの場合には $\left\|\boldsymbol{t}^{\mathrm{coh}}\right\|$ は接線方向 結合力ベクトルの大きさ, $f$ は微視的なせん断強度, $G_{\mathrm{f}}$ は微 視的なせん断破壊エネルギー，火は載荷履歴における微細ひ び割れの最大すべり変位となる.

また, 微細ひび割れの形成を考慮した弱形式は次式になる. 


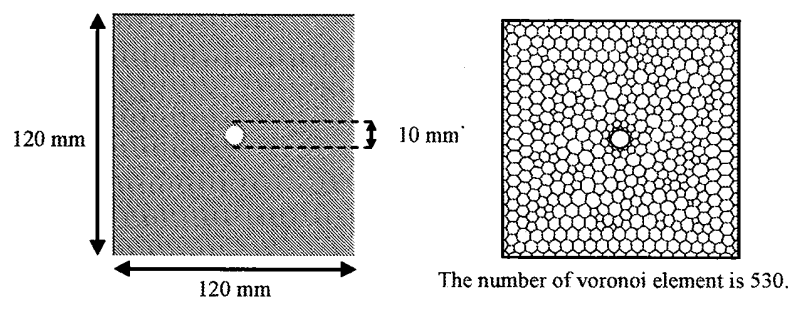

\begin{tabular}{|c|c|}
\hline Young's modulus (MPa) & 20000 \\
\hline Poisson's ratio & 0.2 \\
\hline Tensile strength (MPa) & 1 \\
\hline Tensile fracture energy $(\mathrm{N} / \mathrm{mm})$ & 0.01 \\
\hline Shear strength $(\mathrm{MPa})$ & 6 \\
\hline Shear fracture energy $(\mathrm{N} / \mathrm{mm})$ & 0.4 \\
\hline
\end{tabular}

Fig.2 Analysis model and material parameter

$$
\begin{aligned}
& \int_{S} \delta \boldsymbol{\varepsilon} \cdot \boldsymbol{\sigma} d \Omega+\int_{\Gamma_{\mathrm{EL}}} \delta \boldsymbol{g} \cdot \overline{\boldsymbol{p}}_{\mathrm{W}} \boldsymbol{g} d \Gamma \\
&+\int_{\Gamma_{\mathrm{s}}} \delta \boldsymbol{g} \cdot \boldsymbol{p}_{\mathrm{s}} \boldsymbol{g} d \Gamma+\int_{\Gamma_{\mathrm{n}}} \delta \boldsymbol{g} \cdot \boldsymbol{p}_{\mathrm{n}} \boldsymbol{g} d \Gamma \\
&=\int_{\Omega} \delta \boldsymbol{u} \cdot \overline{\boldsymbol{b}} d \Omega+\int_{\Gamma_{\mathrm{t}}} \delta \boldsymbol{u} \cdot \overline{\boldsymbol{t}} d \Gamma
\end{aligned}
$$

ここで， $\delta \boldsymbol{\varepsilon}$ は仮想ひずみベクトル， $\boldsymbol{\sigma}$ は応力ベクトル,$\delta \boldsymbol{g}$ は微細ひび割えの仮想開口変位べクトル，g住不連続面にお ける相対変位ベクトル， $\Gamma_{\mathrm{EL}}$ は未破壊境界， $\Gamma_{\mathrm{S}}$ 梳接触を伴 う微細ひび割れの境界， $\Gamma_{\mathrm{n}}$ は接触を伴わない微細ひび割れ の境界， $\bar{p}_{\mathrm{w}}$ は弱層を表すペナルティバネ係数行列， $p_{\mathrm{s}}$ はせ ん断破壊を表すペナルティバネ係数行列， $p_{\mathrm{n}}$ 仕引張破壊を表 すペナルティバネ係数行列， $\delta \boldsymbol{u}$ は仮想変位ベクトル， $\boldsymbol{b}$ は物体力ベクトル，i は表面力ベクトルである.

\section{(2) 破填の判定}

未破壊時の $\Gamma_{\mathrm{EL}}$ における境界面上の表面力 $\lambda$ は, バネの反 力として次式のように表せる。

$$
\lambda=\lambda_{\mathrm{n}}+\lambda_{\mathrm{s}}=\bar{p}_{\mathrm{W}} g
$$

ここで, $\lambda_{\mathrm{n}}$ 怯法線方向バネ内力, $\lambda_{\mathrm{s}}$ は接線方向バネ内力で ある.引張破壊の判定はこの表面力を用いて次式のように定 める.

$$
\boldsymbol{g} \cdot \boldsymbol{n}>0 \text { and }\left\|\lambda_{\mathrm{n}}\right\| \cdot f_{\mathrm{t}}=0
$$

ここで, $\boldsymbol{n}$ はボロノイ境界における外向き単位法線べクトル である。また，せん断破壊の判定は次式のように定める。

$$
\boldsymbol{g} \cdot \boldsymbol{n}<0 \text { and }\left\|\lambda_{\mathrm{s}}\right\|-f_{\mathrm{s}}=0
$$

\section{3. 圧縮破壊シミュレーション \\ 3.1 検証条件}

後に比較する和泉ら ${ }^{4)}$ の実験的研究において用いられてい るものと同様の，Fig.2に示すようなモルタルモデルを解析対 象として, 縦方向に一軸圧縮ひずタ $0.2 \%$ \% 100 ステップで与 えることによりひび割れ進展シミュレーションを行った.今 回は, 引張強度 $1 \mathrm{MPa}$, 引張破壊エネルギー $0.01 \mathrm{~N} / \mathrm{mm}$, せん 断強度 $6 \mathrm{MPa}$ ，せん断破壊エネルギーを $0.4 \mathrm{~N} / \mathrm{mm}$ としたケー スの結果を示す。

\section{2 検証結果と考察}

シミュレーション結果をFig.3に示す. なお, Fig.3 (a)の結 果のみ円孔部を拡大して示している．Fig.3 を見てみると， はじめに空隙の上下端から荷重軸方向に引張クラックが発 生し（Fig.3 (a)），斜め方向にせん断クラックが発生するのに 伴い，はじめに荷重軸方向に発生した引張クラックは閉じて

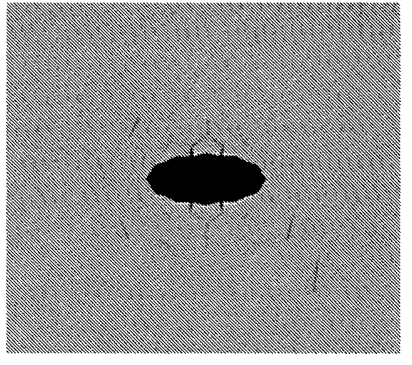

(a) Step: $28 / 100$

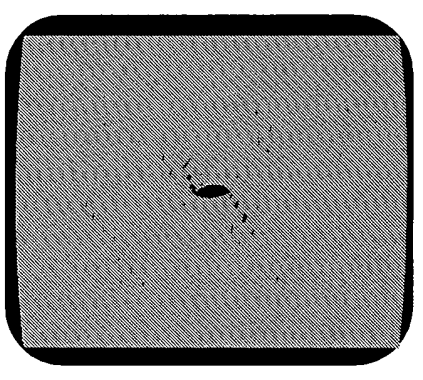

(b) Step: $60 / 100$

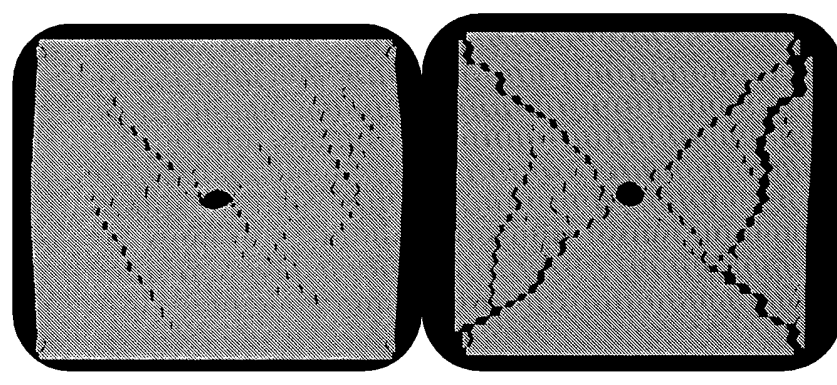

(c) Step: $84 / 100$

(d) Step: $100 / 100$

Fig.3 Simulation results

いる（Fig.3 (b)）。乙して，斜め方向に発生したせん断クラッ クがゆっくりとした速度で成長しつつ, 空隙部以外の部分に おいて荷重軸方向，斜め方向のクラックが生じている（Fig.3 (c)）．その後，4 万向に脆性的にクラックが生じ，全体が崩 壊している（Fig.3(d)).

これらの挙動は和泉らの実験的研究によって示された結 果とほぼ合致している.特に円孔の上下端に生じる引張クラ ックや, 円孔上下端に生じた引張クラックが閉じ, 円孔の斜 め方向へせん断クラックが発生するといった挙動, さらにク ラックもジグザグに進展するといった特徴的な破壊挙動を 再現できている.

\section{4. おわりに}

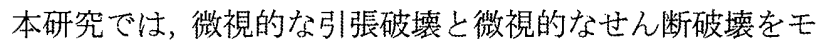
デル化し, モルタルの圧縮破壊進行挙動をシミュレーション により再現することを試みた，その結果，既往の実験的研究 結果とほぼ同様の破壊举動を再現子ることができた。今後の 課題としては, 破壊のモデル化のさらなる検討や材料パラメ 一タの検討, 骨材の有無による影響の考察といったことが挙 げられる。

\section{参考文献}

1) Kohei Nagai, Yasuhiko Sato and Tamon Ueda : Mesoscopic Simulation of Failure of Mortar and Concrete by 2D RBSM, Journal of Advanced Concrete Technology, Vol.2, No3, pp.359-374, 2004.

2) 永井学志, 池田翔太, 胡桃澤清文: 硬化セメントペ 一ストの圧縮強度評価に対する非線形ボクセル有限要 素解法とその適用可能性, 日本計算工学会論文集, Vol. 2010, 20100012, 2010.

3) 車谷麻緒, 寺田 貿二郎, 竹内則雄 : 微細ひび割れの形 成・連結・開閉に起因した準脆性材料の破壊進行メカ二 ズム, 土木工学会論文集 A, Vol.66, No3, pp.505-515, 2010.

4) 和泉正哲, 三橋博三, 佐々木 達夫 : コンクリートの圧 縮破壊発生機構に関する基礎的研究, 日本建築学会論文 報告集，第 289 号, pp.11-25, 1980. 